\title{
Mycorrhizal Inoculation on the Production of Seedlings of Native Caatinga Species
}

\author{
Alan da Cunha Honorato ${ }^{1}$ (D) 0000-0002-5421-4712 \\ João Ricardo Gonçalves de Oliveira² (D) 0000-0003-2192-4256 \\ Aline Magalhães Passos ${ }^{1}$ (D) 0000-0002-6747-0715 \\ Adriana Mayumi Yano-Melo ${ }^{1}$ (D) 0000-0003-2637-7183
}

\begin{abstract}
The objective of this study was to assess the efficiency of a mixed arbuscular mycorrhizal fungi (AMF) inoculum versus a single isolate to promote the seedling development of native Caatinga species: baraúna (Schinopsis brasiliensis Engl.) and juazeiro (Zizyphus joazeiro Mart.). The experiment was conducted in a greenhouse, presenting a completely randomized design with four treatments (Control - not inoculated, inoculated with Claroideoglomus etunicatum, Acaulospora longula or a mix of C. etunicatum and A. longula) and seven replicates. The AMF inoculation promoted an increase in all growth variables of the two plant species, with increments above $100 \%$ in all inoculation treatments, and a significant reduction in the transplanting time of the seedlings to the field. We concluded that the AMF use under study in the mixed form is as beneficial as in the isolated form for Z. joazeiro and S. brasiliensis seedling production.
\end{abstract}

Keywords: Mycorrhiza, growth promotion, Zizyphus joazeiro, Schinopsis brasiliensis.

\section{INTRODUCTION AND OBJECTIVES}

The Caatinga is the only biome whose limits are restricted to the Brazilian national territory; however, this is the least studied and protected biome among the Brazilian regions with only $4 \%$ of its territory being considered a conservation unit, which contributes to the unsustainable use of its resources (Drummond et al., 2011). Among the several anthropic activities that have contributed to the unsustainable use of the Caatinga biome, the extractive exploitation of some plant species has caused strong pressure on the landscape of the semi-arid region (Siqueira Filho, 2012). Therefore, planting native seedlings is an alternative to recover the devastated areas (Siqueira Filho, 2012). However, the production of native seedlings is still incipient and poorly stimulated, mainly due to the low cost-benefit ratio due to the high cost of fertilizers and the long stay in the nursery for most of these plants (Silva et al., 2015).

Thus, using arbuscular mycorrhizal fungi (AMF) in the seedling production phase has been considered a very promising alternative to reduce costs in producing some cultivated species such as passion fruit (Passiflora alata Sims f. flavicarpa Deg.) (Oliveira, Campos et al., 2015), acerola cherry (Malpighia emarginata DC.) (Balota et al., 2011), coffee (Coffea arabica L.) (França et al., 2014), peaches (Prunus persica (L.) Batsch) (Nunes et al., 2013), among others. Seedlings inoculated with AMF present many benefits; among them we can mention their survival, which is often increased due to the adaptation to environmental variations induced by several mechanisms, i.e., greater development of the root system and the photosynthetically active area, as well as greater water and nutrient absorption (Smith \& Read, 2008).

Some studies have shown mycorrhizal colonization in some species of Caatinga vegetation, such as angico (Anadenanthera macrocarpa and A. colubrina) (Pedone-Bonfim et al. 2013; Sugai et al., 2011), sabiá (Mimosa caesalpiniifolia Benth.) (Tavares et al., 2012), leucaena (Leucaena leucocephala L.) (Oliveira et al., 2013), baraúna (Schinopsis brasiliensis Engl.) (Oliveira, Teixeira-Rios et al., 2015), jurema (Mimosa tenuiflora (Willd.) Poir.) (Teixeira-Rios et al., 2016), Brazilian orchid tree (pata-de-vaca) (Bauhinia forficata Link.) (Nascimento et al., 2014), among others. However, few studies have focused on the contribution of this symbiosis to the survival and development of native plants, mainly in the Caatinga biome

\footnotetext{
${ }^{1}$ Universidade Federal do Vale do São Francisco (UNIVASF), Petrolina, PE, Brasil

${ }^{2}$ Universidade Federal da Paraíba (UFPB), João Pessoa, PB, Brasil
} 
(Maia et al., 2010). It is estimated that less than $1 \%$ of the plant species reported in this biome have been studied regarding their potential symbiosis benefit (Pedone-Bonfim et al., 2017).

Mendes et al. (2013) identified that sabiá (Mimosa caesalpiniifolia Benth.) seedlings presented an increase in height, stem diameter, $\mathrm{N}$ and $\mathrm{P}$ contents when inoculated with Gigaspora margarita, both in greenhouse and field. On the other hand, Nascimento et al. (2014) showed that the soil type affected the mycorrhizal efficiency, because in Quatzarenic Neosol soil it was verified that inoculation with Claroideoglomus etunicatum (isolated UNIVASF 06) provided higher height, leaf area, fresh biomass and dry biomass of moraino plants (Bauhinia cheilantha), but these benefits were not observed in grayish Argisol. Recently, Oliveira, Teixeira-Rios et al. (2015) showed an inoculation benefit with Claroideoglomus etunicatum (isolated UNIVASF 06) and Acaulospora longula (isolated UNIVASF 12) in improving the seedling production of Schinopsis brasiliensis (baraúna), even in Yellow Argisol. Similarly, Teixeira-Rios et al. (2016) observed a growth increase in Mimosa tenuiflora (jurema) plants mainly inoculated with C. etunicatum (isolated UNIVASF 06) in soil with low phosphorus concentration. This study evidences the importance of selecting the AMF inoculum for the plant species that will be produced, since the same AMF isolate can provide different development depending on the soil and the associated plant.

Thus, the need to better understand the interaction between AMF and plant species is evident (Smith \& Smith, 2012), especially those of the Caatinga when thinking about a seedling production system. However, considering that AMF is not specific to plant species (Smith \& Read, 2008), a proposal of a mixed inoculum may be more viable for commercialization since AMF isolates may present strategies for root colonization and acquisition of different nutrients (Jansa et al., 2008), resulting in complementary functionality.

In this sense, this study tests the hypothesis that mixed AMF inocula would be more efficient to promote seedling development of native Caatinga species of baraúna (Schinopsis brasiliensis Engl.) and juazeiro (Zizyphus joazeiro Mart.).

\section{MATERIALS AND METHODS}

\subsection{Plant material and experiment conduction}

The soil used (Yellow Argisol) in the experiment and the baraúna and juazeiro seeds were collected in Caatinga area in the Experimental Field of Embrapa Semiarid, located in Petrolina (9॰ 4' $8.0^{\prime \prime}$ S, $40^{\circ} 19^{\prime} 18.4^{\prime \prime} \mathrm{W}$ ). The soil had the following chemical and physical characteristics: Organic matter (O.M.) $=10.96 \mathrm{~g} \mathrm{~kg}^{-1} ; \mathrm{pH}=5.8$; electrical conductivity
$(\mathrm{EC})=0.51 \mathrm{dS} \mathrm{m}^{-1}$; phosphorus $(\mathrm{P})=6.14 \mathrm{mg} \mathrm{dm}^{-3} ;$ potassium $(\mathrm{K})=0.35 \mathrm{cmolc} \mathrm{dm}^{-3}$; calcium $(\mathrm{Ca})=1.5 \mathrm{cmolc} \mathrm{dm}^{-3}$; magnesium $(\mathrm{Mg})=1 \mathrm{cmolc} \mathrm{dm}^{-3} ;$ sodium $(\mathrm{Na})=0.03 \mathrm{cmolc} \mathrm{dm}^{-3}$; exchangeable acidity $\left(\mathrm{Al}^{3+}\right)=0.1 \mathrm{cmolc} \mathrm{dm}^{-3}$; potential acidity $(\mathrm{H}+\mathrm{Al})=4.62$; base sum $(\mathrm{BS})=2.88$; cation exchange capacity $(\mathrm{CEC})=7.5 \mathrm{cmolc} \mathrm{dm}^{-3}$; base saturation $(\mathrm{V})=38 \%$; Sand $=77.26 \%$; Silt $=14.81 \%$; Clay $=7.93 \%$. After the collection, the soil was sifted to remove stones, roots and other debris; the soil was disinfected in an autoclave at $121{ }^{\circ} \mathrm{C}$ for three cycles of 1 hour and oven dried at $60^{\circ} \mathrm{C}$, remaining in plastic bags until the moment of use.

The seeds were collected between August and September 2012, cut in the integument portion opposite to the embryo. Then they were disinfected by immersion in $0.05 \%$ sodium hypochlorite solution for 20 minutes (Couto et al., 2004), washed three times with distilled water and seeded in trays containing medium particle size vermiculite. The trays were kept in a greenhouse for 30 days, being sufficient time for seedling emergence and emergence of three definitive leaves on the seedlings. Then the seedlings were transferred to plastic cups $(200 \mathrm{~mL})$ containing 1:1:1 (v/v/v) sand, soil and vermiculite, and inoculated or not with AMF according to the treatments. The sand used for sowing was sieved and rested with sodium hypochlorite solution $(5 \% \mathrm{NaOCl})$ diluted to $0.05 \%(\mathrm{v} / \mathrm{v})$ for $12 \mathrm{~h}$, then successively washed with tap water and it was maintained at room temperature for drying. After this process the sand was autoclaved at $121^{\circ} \mathrm{C}$ for 1 hour on three consecutive days and left in plastic bags for at least 10 days in ambient condition for later use.

After 15 days, seedlings were transferred to plastic pots containing $1.5 \mathrm{~kg}$ of previously disinfected soil (Yellow Argisol). The seedlings were irrigated daily with $50 \mathrm{~mL} / \mathrm{vial}$ of tap water up to the $45^{\text {th }}$ day. The water volume was then doubled due to the plants increased water demand from this period until the end of the experiment (90 days), using $100 \mathrm{~mL} /$ pot.

\subsection{AMF isolates and the inoculation process}

Two AMF isolates were tested: Claroideoglomus etunicatum (Becker \& Gerd.) C. Walker \& A. Schüssler (isolated UNIVASF 06) and Acaulospora longula Spain \& N.C. Schenck (isolated URM FMA 07), as well as a mixed inoculum composed of the two AMF isolates in an equivalent proportion of glomerospores. All isolates were multiplied in culture on farm; the sorghum (Sorghum bicolor (L.) Moench) was grown as a multiplying plant with its substrate containing expanded clay: previously disinfected sand $(1: 1 \mathrm{v} / \mathrm{v})$ and supplemented with $5 \%$ leucaena + crushed sugarcane $(1: 1 \mathrm{v} / \mathrm{v})$ for producing C. etunicatum propagules, and $5 \%$ of crushed leucaena in the case of $A$. longula. 
The AMF inoculation occurred in soil-inoculum (containing soil, colonized roots, hyphae and glomerospores), both inocula had about 280 infective propagules $/ \mathrm{cm}^{3}$. About $4 \mathrm{~g}$ soil-inoculum of Claroideoglomus etunicatum or Acaulospora longula were inoculated per plant, which were composed of 200 glomerospores, and approximately $2 \mathrm{~g}$ of soil-inoculum of each isolate was applied for the mixed inoculate (corresponding to 100 glomerospores of each isolate). All steps were conducted in the greenhouse of Universidade Federal do Vale do São Francisco (UNIVASF), Campus Ciências Agrárias.

\subsection{Evaluated parameters}

The plants were assessed twice a week for height (HT) and number of leaves (NL) variables 30 days after AMF inoculation. The length of the plant stem was measured using a measuring tape until the end of the apical meristem, for HT. The leaves for NL were considered totally expanded.

At the end of the experiment (90 days after inoculation), in addition to the HT and NL variables, the leaf area (LA), proportional increase, fresh shoot biomass (FSB) and fresh root biomass (FRB), dry shoot biomass (DSB), dry root biomass (DRB), mycorrhizal colonization (MC), and number of glomerospores (NG) were assessed.

The image was captured using a digital camera and this variable was measured using the Quant program. 1.0.1 (Vale et al., 2003), for LA. The proportional increment was calculated using the equation of Weber et al. (2004), described below (Equation 1).

$$
\mathrm{I}(\%)=\left[(\mathrm{X}-\mathrm{Y}) \mathrm{Y}^{-1}\right] \times 100
$$

Where I (\%): variable increment; X: mean value for inoculated treatment; Y: mean value of non-inoculated treatment.

The plants were cut at the stem base and immediately weighed on a semi-analytical scale to determine the FSB. The FRB was measured by sieving the soil and collecting the roots in a sieve $(1.0 \mathrm{~mm})$, with subsequent washing and delicate drying on paper towels; a semi-analytical scale was used for weighing. Then, FSB and FRB material was put into a drying oven with forced circulation and it was maintained at $65^{\circ} \mathrm{C}$ until reaching constant weight, resulting in DSB and DRB, respectively. The FRB of the baraúna seedlings of the non-inoculated treatment was used in its entirety to assess mycorrhizal colonization, and it was not possible to obtain the DRB from this treatment.

To determine $\mathrm{MC}$, the roots of each plant species were separated from the soil, washed, weighed $(0.5 \mathrm{~g})$, clarified with $\mathrm{KOH}$ solution (10\%) for 24 hours and stained with $0.05 \%$ Trypan blue in lactoglycerol, following the method of Phillips \& Hayman (1970); the mycorrhizal colonization percentage was assessed by the intersection method of the quadrants (Giovanetti \& Mosse, 1980). NG was quantified based on $50 \mathrm{~g}$ of soil aliquots from each experimental unit after extracting glomerospores by wet sieving and centrifugation in water for 3 minutes at 2,500 rpm, and $40 \%$ sucrose for 1 minutes at 2,500 rpm (Gerdeman \& Nicolson, 1963; Jenkins, 1964), and counting with a stereomicroscope.

\subsection{Experimental design and statistical analysis}

The experiment was conducted in a completely randomized design with four AMF inoculation treatments - non-inoculated (NI), inoculated with Claroideoglomus etunicatum (CE), or Acaulospora longula (AL), or a mix of $C$. etunicatum and A. longula (Mix) -, in seven replicates, with each experimental unit consisting of one plant. Data were submitted to analysis of variance by the $F$-test for a diagnosis of significant effect, and the treatments were compared by the Duncan's test $(p<0.05)$, with analyzes being performed by the Sisvar version 5.1 statistical program. We also performed a correlation analysis between the variables using the Pearson method $(|\mathrm{r}|>0.50)$ with the R program (R Core Team, 2016), and the graphs were made using SigmaPlot, version 11.0 (Systat Software, San Jose, CA).

\section{RESULTS AND DISCUSSION}

The effect of AMF inoculation was more evident in juazeiro seedlings, since in the first experiment assessment (30 days after inoculation) mycorrhizal plants were significantly superior in HT (Figure 1a) and NL (Figure 1b). On the other hand, the mycorrhizal inoculation effects in baraúna were evidenced later, with significance after approximately 60 days of inoculation (Figure $1 \mathrm{c}$ and $1 \mathrm{~d}$ ). The response speed to mycorrhizal inoculation may be the difference between the growth rates of these plant species and/or the functional compatibility between the symbionts, which varies as a function of the fungus-plant interaction to environmental conditions (Folli-Pereira et al., 2012).

According to Scremin-Dias's et al. (2006) manual on seedling production of forest species, seedlings must have a single stem filled with leaves with a wide leaf area, and an ideal height of 20 to 35 centimeters to be transplanted to the field, although these factors vary among species. When considering these characteristics, mycorrhizal juazeiro plants reached ideal height for transplantation to the field at 60 days (Figure 1a), while mycorrhizal baraúna plants were near to their ideal size at 90 days (Figure 1c). These results indicate a significant time reduction in seedling production, since the non-mycorrhized plants of both species studied did not exceed $12 \mathrm{~cm}$ at 90 days. 

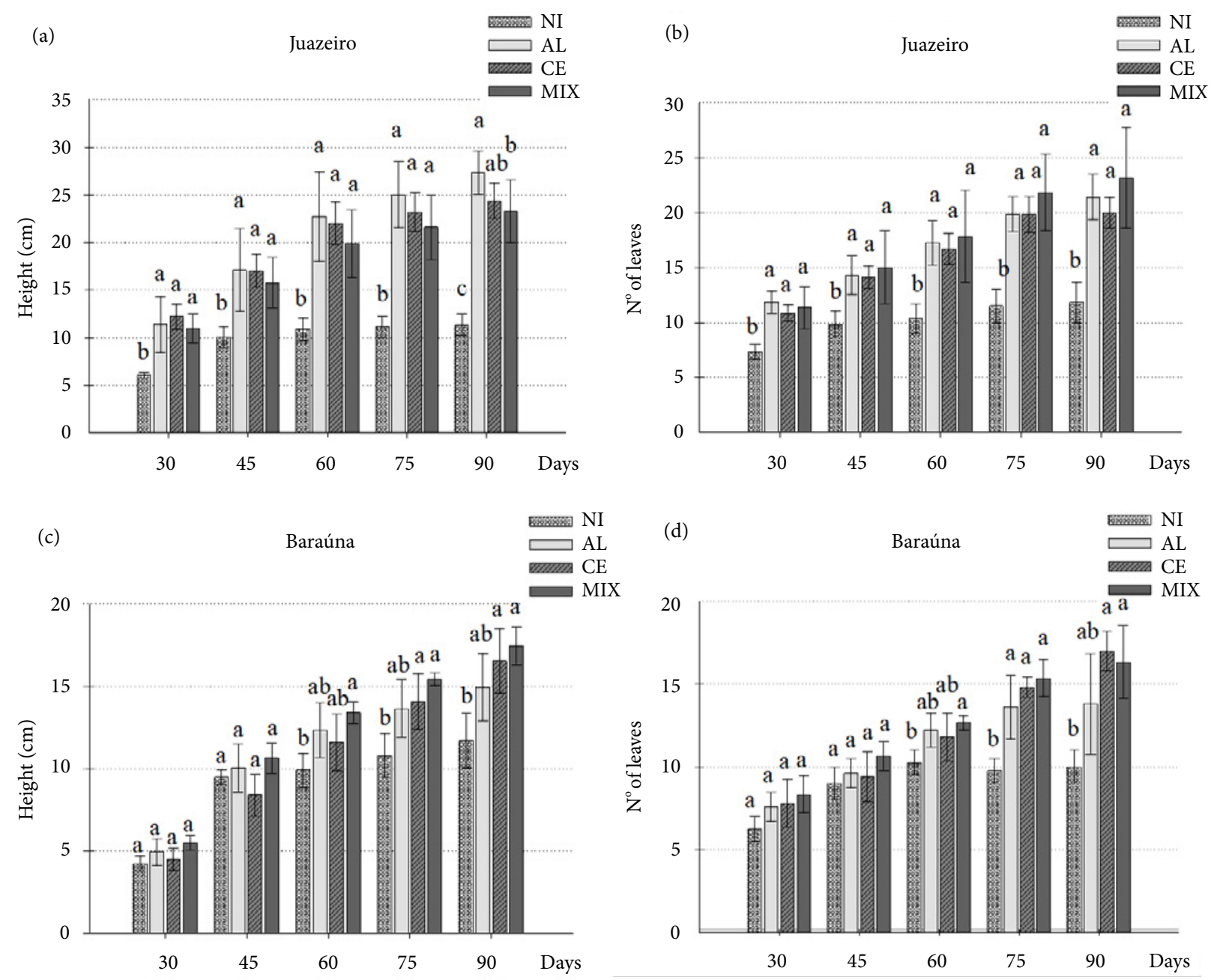

Figure 1. Height and average number of leaves of juazeiro (Z. joazeiro) and baraúna (S. brasiliensis) plants as a function of arbuscular mycorrhizal fungi inoculation treatments after 30, 45, 60, 75 and 90 days of cultivation.

${ }^{*}$ Bars with equal letters at each time do not differ by Duncan's test ( $\left.p<0.05\right)$. NI: treatments: non-inoculated; CE: inoculated with C. etunicatum; AL: A. longula; or Mix: mixed inoculum of the isolates, after 90 days of cultivation in the greenhouse conditions.

All analyzed growth variables presented a significant effect on AMF inoculation: height (HT), number of leaves (LN), leaf area (LA), fresh and dry shoot biomass (FSB/DSB) and fresh and dry root biomass (FRB/DRB); a significant effect also occurred for the variables related to mycorrhization such as the number of glomerospores (NG) and mycorrhizal colonization (MC) of juazeiro (Ziziphus joazeiro) and baraúna (Schinopsis brasiliensis) seedlings (Table 1).

AMF inoculation significantly increased growth variables in juazeiro plants, differing from control for all assessed variables (Table 1). For this same plant species, a significant difference was found for HT, FRB and DRB among AMF isolates, with an emphasis on seedlings inoculated with A. longula (AL). In the same way, mycorrhization provided positive results for most of the growth variables in baraúna, with an emphasis on inoculation with C. etunicatum (CE) and mixed inoculum (Table 1). These benefits provided by mycorrhization were also observed in baraúna (Schinopsis brasiliensis) (Oliveira, Teixeira-Rios et al., 2015) and juazeiro (Oliveira et al., 2017) plants cultivated in soil with low phosphorus concentration $\left(6.14 \mathrm{mg} \mathrm{dm}^{-3}\right)$, which presented higher leaf area and vegetative development when inoculated with these same isolates.

The highest values NL (23 and 17 leaves per plant) were observed in juazeiro and baraúna plants, respectively, with the application of mixed inoculum and CE (Table 1 and Figure 1). The highest mean values of $\mathrm{HT}(27.3$ and $17.5 \mathrm{~cm})$ were obtained with the AL inoculum and mixed inoculum, respectively, for juazeiro and baraúna (Table 1 and Figure 1). The AL inoculum also provided the greatest LA expansion in 
juazeiro $\left(183.2 \mathrm{~cm}^{2}\right)$, not differing from the other inoculated treatments, but the highest value in baraúna $\left(138.3 \mathrm{~cm}^{2}\right)$ was reached with $\mathrm{CE}$ inoculum, significantly differing from $\mathrm{AL}$ and control (Table 2). For fresh and dry shoot biomass (FSB and DSB, respectively) and fresh and dry root biomass (FRB and DRB, respectively), there was no statistical difference between the treatments inoculated with AMF in either plant species, except for FRB and DRB in juazeiro, where AL inoculation provided the highest FRB $(1.7 \mathrm{~g})$ and $\mathrm{CE}$ inoculation the lowest DRB $(0.5 \mathrm{~g})$.

The different responses to the mycorrhization presented by the plant species ( $Z$. joazeiro and $S$. brasiliensis) are probably related to different interactions of host species and/ or AMF species in the environment. Notably, the fungusplant interaction is a complex biological process regulated by both partners, causing a wide range of outcomes between different plants and fungi species (Smith \& Read, 2008). In a study with avocado (Persea americana) mycorrhized with different species of fungi (isolated and together), Violi et al. (2007) also identified different responses to inoculation in the growth and phosphorus absorption $(\mathrm{P})$ variables; for these authors, the carbon cost (C) in host-AMF interactions may vary, especially if these fungi are used in a mix or alone. On the other hand, Knegt et al. (2016) found no difference in the benefit provided to height and biomass of the plants between treatments with mixed and isolated inocula, but they emphasize that the root colonization by one of the AMF isolates can reduce subsequent colonization by another AMF species.

In this study, we could not distinguish root colonization by species, since unlike the studies by Engelmoer et al. (2014), which used qPCR, the assessment was only performed morphologically. It is observed that MC in both plant species in the inoculated treatments was higher than $84 \%$ (Table 1), thus emphasizing that these AMF isolates provide extensive colonization in the roots of these plant species. Lins et al. (2007) also observed high colonization percentages with these two mycorrhizal fungi species in Leucaena leucocephala 110 days after inoculation in soil from the Caatinga. However, Balota et al. (2011) emphasize that the percentage of root colonization does not directly reflect the plant response due to several other factors such as the production of external mycelium.

Percentages of root colonization lower than $1.5 \%$ were observed in treatments with no inoculation, since this soil underwent previous disinfection under high temperature and pressure. Thus, the mycorrhizal colonization found may be associated with contamination via water or wind.

In this work it was possible to observe that each plant species had better interaction with a specific fungus. In juazeiro, the best growth responses were observed with the inoculation of the $A$. longula isolate, providing increases of $307 \%$ in LA (Figure 2a), $680 \%$ in DSB (Figure 2b) and 2,585\% in DRB (Figure 2c); while C. etunicatum was more favorable for baraúna, increasing LA by $292 \%$ (Figure 3a) and DSB by $420 \%$ (Figure $3 \mathrm{~b}$ ). Gosling et al. (2013) observed a strong specificity between host species and AMF through molecular analyzes of the isolates in the hosts. Similar behavior was also detected in different fungus-plant combinations of tropical tree species by Pouyu-Rojas et al. (2006), demonstrating that some selectivity may occur in combinations of fungi and plants.

Table 1. Means of height, number of leaves, leaf area, fresh shoot biomass, dry shoot biomass, fresh root biomass, dry root biomass, mycorrhizal colonization and number of glomerospores in juazeiro (Z. joazeiro) and baraúna (S. brasiliensis) plants from AMF inoculation treatments.

\begin{tabular}{|c|c|c|c|c|c|c|c|c|c|}
\hline \multirow{3}{*}{ Treatments } & \multicolumn{8}{|c|}{ Juazeiro } & \multirow[b]{2}{*}{ NG } \\
\hline & HT & NL & LA & FSB & DSB & FRB & DRB & MC & \\
\hline & $\mathbf{c m}$ & & $\mathrm{cm}^{2}$ & \multicolumn{4}{|c|}{---------------'g--------------- } & $\%$ & (g/soil) \\
\hline NI & $11.3 \mathrm{c}$ & $11.8 \mathrm{~b}$ & $45.0 \mathrm{~b}$ & $0.4 \mathrm{~b}$ & $0.2 \mathrm{~b}$ & $0.1 \mathrm{c}$ & $0.1 \mathrm{c}$ & $0.3 \mathrm{~b}$ & $4.1 \mathrm{~b}$ \\
\hline $\mathrm{AL}$ & $27.3 \mathrm{a}$ & $21.4 \mathrm{a}$ & $183.2 \mathrm{a}$ & $2.7 \mathrm{a}$ & $1.4 \mathrm{a}$ & $1.7 \mathrm{a}$ & $0.9 \mathrm{a}$ & $94.0 \mathrm{a}$ & $10.0 \mathrm{a}$ \\
\hline CE & $24.4 \mathrm{ab}$ & $20.0 \mathrm{a}$ & $161.9 \mathrm{a}$ & $2.4 \mathrm{a}$ & $1.2 \mathrm{a}$ & $0.9 \mathrm{~b}$ & $0.5 \mathrm{~b}$ & $84.3 \mathrm{a}$ & $10.1 \mathrm{a}$ \\
\hline Mix & $23.0 \mathrm{~b}$ & $23.2 \mathrm{a}$ & $170.1 \mathrm{a}$ & $2.3 \mathrm{a}$ & $1.1 \mathrm{a}$ & $1.1 \mathrm{~b}$ & $0.7 \mathrm{ab}$ & $91.8 \mathrm{a}$ & $11.2 \mathrm{a}$ \\
\hline \multicolumn{10}{|c|}{ Baraúna } \\
\hline NI & $11.7 \mathrm{~b}$ & $10.0 \mathrm{~b}$ & $35.2 \mathrm{c}$ & $0.4 \mathrm{~b}$ & $0.2 \mathrm{~b}$ & $0.4 \mathrm{~b}$ & $* *$ & $1.5 \mathrm{~b}$ & $8.4 \mathrm{c}$ \\
\hline $\mathrm{AL}$ & $15.0 \mathrm{ab}$ & $13.8 \mathrm{ab}$ & $101.6 \mathrm{~b}$ & $1.7 \mathrm{a}$ & $0.7 \mathrm{a}$ & $1.6 \mathrm{a}$ & 0.4 & $90.8 \mathrm{a}$ & $13.2 \mathrm{~b}$ \\
\hline CE & $16.5 \mathrm{a}$ & $17.0 \mathrm{a}$ & $138.3 \mathrm{a}$ & $2.1 \mathrm{a}$ & $1.0 \mathrm{a}$ & $1.4 \mathrm{ab}$ & 0.5 & $87.8 \mathrm{a}$ & $14.8 \mathrm{ab}$ \\
\hline Mix & $17.5 \mathrm{a}$ & $16.3 \mathrm{a}$ & $120.5 \mathrm{ab}$ & $1.9 \mathrm{a}$ & $0.8 \mathrm{a}$ & $1.5 \mathrm{ab}$ & 0.6 & $93.3 \mathrm{a}$ & $15.5 \mathrm{a}$ \\
\hline
\end{tabular}

* Averages of the same letter in the column for each species did not differ from each other by Duncan's test $(p<0.05)$. ${ }^{*}$ The entire root system was used to assess mycorrhizal colonization. Treatments: NI: non-inoculated; CE: inoculated with C. etunicatum; AL: inoculated with A. longula; or Mix: mixed inoculum of isolates, after 90 days of cultivation under greenhouse conditions. HT: means of height; NL: number of leaves; LA: leaf area; FSB: fresh shoot biomass; DSB: dry shoot biomass; FRB: fresh root biomass; DRB: dry root biomass; MC: mycorrhizal colonization; NG: number of glomerospores. 
(a)

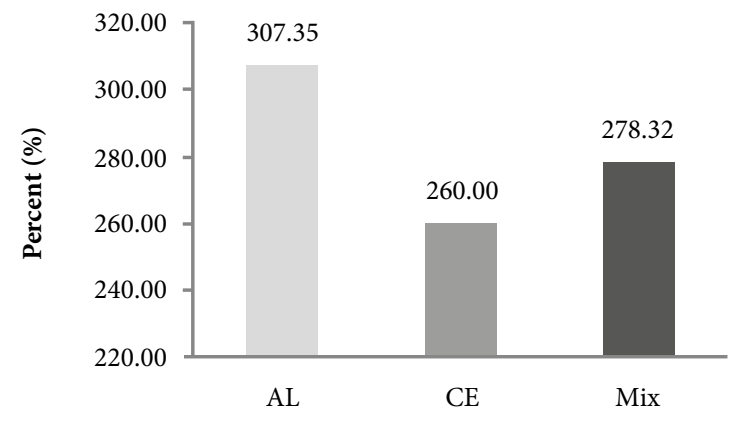

(b)

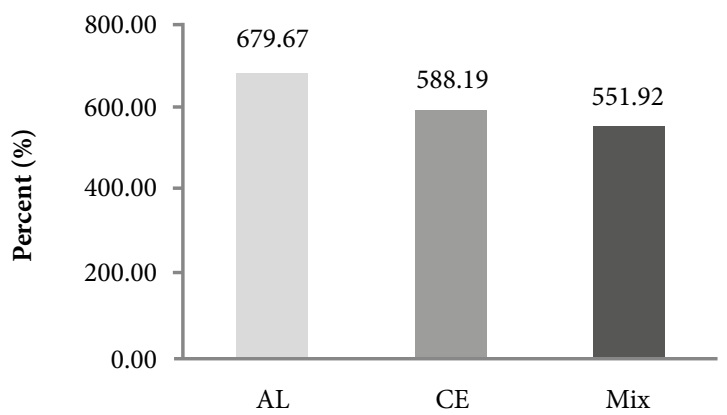

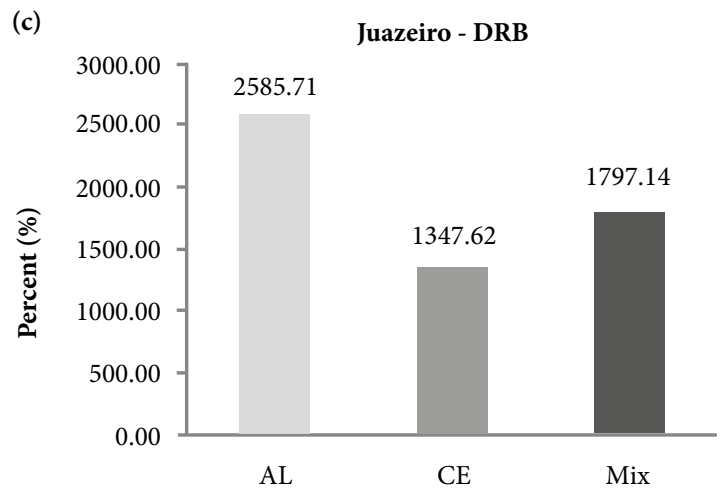

Figure 2. Proportional increase of leaf area, dry shoot biomass and dry root biomass in juazeiro (Z. joazeiro) plants as a function of arbuscular mycorrhizal fungi inoculation treatments, Petrolina, PE.

* Treatments: CE: inoculated with C. etunicatum; AL: inoculated with A. longula; or Mix: mixed inoculum of the isolates, after 90 days of cultivation under greenhouse conditions. LA: leaf area; DSB: dry shoot biomass; DRB: dry root biomass.

(a)

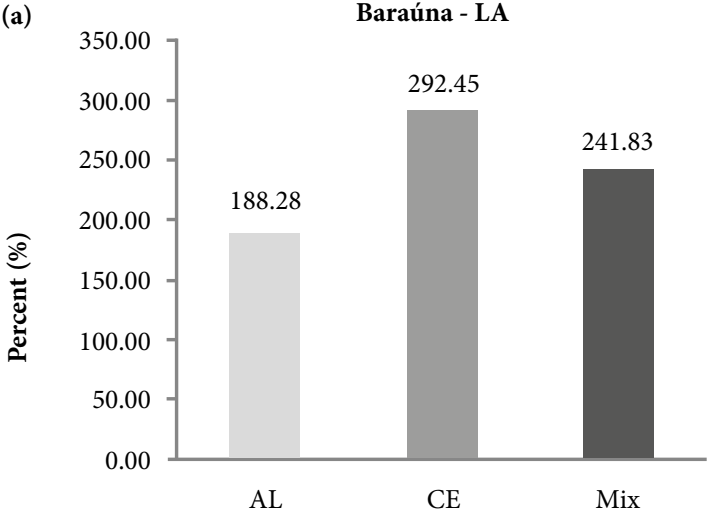

(b)

Baraúna - LA

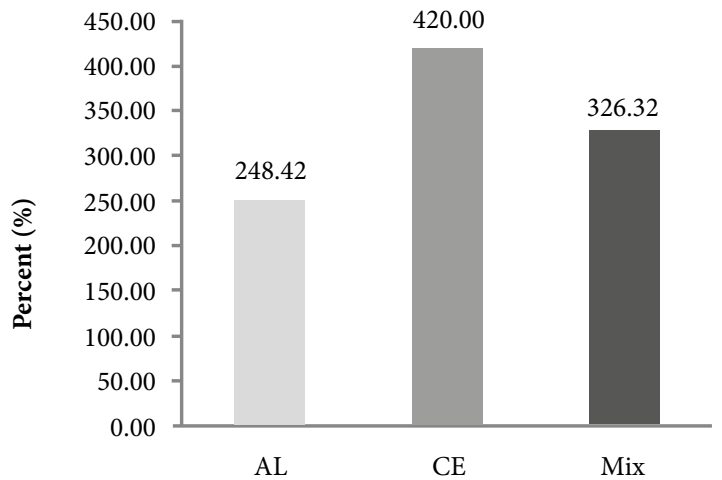

Figure 3. Proportional increase of leaf area and dry shoot biomass in baraúna (S. brasiliensis) plants as a function of arbuscular mycorrhizal fungi inoculation treatments, Petrolina, PE.

* Treatments: CE: inoculated with C. etunicatum; AL: A. longula; or Mix: mixed inoculum of the isolates, after 90 days of cultivation under greenhouse conditions. LA: leaf area; DSB: dry shoot biomass. 
The use of mixed inoculant promoted positive results in growth; however, these data do not provide evidence about a functional synergism of AMF in providing benefits to the plant, partly corroborating the results obtained by Violi et al. (2007), which did not identify an increase in plant growth rate and nutrient uptake with the use of two AMF isolates in avocado (Persea americana) when compared to isolated inoculation of these fungi. Considering the results obtained with the mixed inoculant treatment, the use of this inoculum may be an interesting strategy for nurseries that produce several species of native plants from Caatinga, since different AMF species may present different results to establish symbiosis with a certain plant in certain environmental conditions (Smith \& Smith, 2012). Thus, we can understand how relevant the knowledge of this extent of results and AMF diversity are for environmental rehabilitation, especially in places where low fertility soils predominate (Pouyu-Rojas et al., 2006).

In the seedlings of the two analyzed plant species, in particular juazeiro, it was possible to observe a strong positive correlation with a high level of significance between $\mathrm{MC}$ and other plant growth variables, especially HT, FSB, DSB and LA (Table 2), confirming the contribution of mycorrhization to plant development. Similar correlations were found by Nunes et al. (2013) when assessing the influence of AMF species (Glomus clarum = Rhizophagus clarus and Glomus etunicatum = C. etunicatum), on the development of peach seedlings. AMFs may or may not be effective in stimulating plant growth, considering that under certain conditions, these fungi may establish extensive colonization without providing improvement in host growth; thus, the same AMF isolate may be associated with many plant species, but the effectiveness of this combination may vary considering the ability of some fungal species to develop an extensive mycelial network, increasing the absorption of phosphorus $(\mathrm{P})$ and other nutrients (Carvalho et al., 2014).

The increase promoted by mycorrhization may be due to the enlargement of the root system observed in inoculated plants, since a positive and significant correlation between MC and DRB (Table 2) occurred. The increase in the root biomass enables greater absorption of nutrients from the soil, and there may be extraradicle mycelium contribution of the AMF, which enables a greater area of soil exploration and consequently greater potential for nutrient absorption, such as P, as observed by Saboya et al. (2012) in the raise of the P content in mycorrhizal Jatropha curcas. It is worth noting that $P$ is a nutrient closely related to root system development (Novais et al., 2007), and the high correlation between MC and DRB indicates that plants inoculated with AMFs may have absorbed more of this nutrient.

Table 2. Correlation between the studied variables.

\begin{tabular}{|c|c|c|c|c|c|c|c|c|c|}
\hline & \multicolumn{9}{|c|}{ Juazeiro } \\
\hline & HT & NL & FSB & DSB & FRB & DRB & NG & MC & LA \\
\hline $\mathrm{HT}$ & 1 & $0.61^{* *}$ & $0.96^{* *}$ & $0.96^{* *}$ & $0.82^{* *}$ & $0.82^{* *}$ & $0.59^{*}$ & $0.90^{* *}$ & $0.86^{* *}$ \\
\hline NL & - & 1 & $0.70^{* *}$ & $0.70^{* *}$ & $0.60^{* *}$ & $0.56^{* *}$ & $0.59^{*}$ & $0.74^{* *}$ & $0.81^{* *}$ \\
\hline FSB & - & - & 1 & $0.99^{* *}$ & $0.80^{* *}$ & $0.80^{* *}$ & $0.60^{*}$ & $0.89^{* *}$ & $0.90^{* *}$ \\
\hline DSB & - & - & - & 1 & $0.77^{* *}$ & $0.76^{* *}$ & $0.58^{*}$ & $0.88^{* *}$ & $0.90^{* *}$ \\
\hline FRB & - & - & - & - & 1 & $0.98^{* *}$ & $0.52^{*}$ & $0.76^{* *}$ & $0.82^{* *}$ \\
\hline DRB & - & - & - & - & - & 1 & $0.55^{*}$ & $0.75^{* *}$ & $0.82^{* *}$ \\
\hline NG & - & - & - & - & - & & 1 & $0.72^{* *}$ & $0.62^{* *}$ \\
\hline $\mathrm{MC}$ & - & - & - & - & - & - & - & 1 & $0.89^{* *}$ \\
\hline \multirow[t]{3}{*}{ LA } & - & - & - & - & - & - & - & - & 1 \\
\hline & \multicolumn{7}{|c|}{ Baraúna } & & \\
\hline & HT & NL & FSB & DSB & FRB & NG & MC & LA & \\
\hline HT & 1 & $0.66^{* *}$ & $0.72^{* *}$ & $0.46^{\mathrm{ns}}$ & $0.18^{\mathrm{ns}}$ & $0.61^{* *}$ & $0.62^{* *}$ & $0.73^{* *}$ & \\
\hline NL & - & 1 & $0.87^{* *}$ & $0.72^{* *}$ & $0.44^{\mathrm{ns}}$ & $0.51^{*}$ & $0.64^{* *}$ & $0.81^{* *}$ & \\
\hline FSB & - & - & 1 & $0.83^{* *}$ & $0.62^{* *}$ & $0.74^{* *}$ & $0.86^{* *}$ & $0.95^{* *}$ & \\
\hline DSB & - & - & - & 1 & $0.48^{\mathrm{ns}}$ & $0.64^{* *}$ & $0.68^{* *}$ & $0.82^{* *}$ & \\
\hline FRB & - & - & - & - & 1 & $0.58^{\mathrm{ns}}$ & $0.62^{* *}$ & $0.48^{*}$ & \\
\hline NG & - & - & - & - & - & 1 & $0.88^{* *}$ & $0.79^{* *}$ & \\
\hline $\mathrm{MC}$ & - & - & - & - & - & - & 1 & $0.82^{* *}$ & \\
\hline LA & - & - & - & - & - & - & - & 1 & \\
\hline
\end{tabular}

${ }^{* *}$ Significant at $1 \%$ of probability; ${ }^{*}$ Significant at $5 \%$ of probability; ${ }^{\text {ns }}$ Not significant; HT: height; NL: number of leaves; FSB: fresh shoot biomass; DSB: dry shoot biomass; FRB: fresh root biomass; DRB: dry root biomass; NG: number of glomerospores; MC: mycorrhizal colonization; LA: leaf area. 
The correlation analysis also identified a strong positive correlation with a high level of significance between $\mathrm{MC}$ and the number of glomerospores (NG) in the two studied plant species (Table 2). This result was not observed by Oliveira, Teixeira-Rios et al. (2015), who reported a low correlation between mycorrhizal colonization and sporulation of these same isolates in baraúna. For Nascimento et al. (2014), several abiotic factors can influence NG, such as soil type, humidity, $\mathrm{pH}$, and temperature; however, Violi et al. (2007) emphasized that the interaction between plant species and fungal isolates are also determinants in sporulation.

\section{CONCLUSIONS}

The use of arbuscular mycorrhizal fungi to produce seedlings of native species such as juazeiro and baraúna is beneficial to promote greater growth and may reduce the formation time of the seedlings, thus making its use in large scale production possible.

There is a specific beneficial combination between A. longula (URM FMA07) and juazeiro seedlings, and between C. etunicatum (UNIVASF 06) and baraúna seedlings. However, the strategic use of the mixed inoculum composed of A. longula and C. etunicatum may be the best alternative in commercial nurseries for native Caatinga plants.

\section{ACKNOWLEDGEMENTS}

The authors thank the Universidade Federal do Vale do São Francisco (UNIVASF) and Embrapa Semiárido for their support in this research.

\section{SUBMISSION STATUS}

Received: 28 Dec. 2017

Accepted: 31 Aug. 2018

Associate editor: José Henrique Tertulino Rocha

\section{CORRESPONDENCE TO}

\section{Alan da Cunha Honorato}

Rua Raimunda Ventura de Souza Brandão, 50, CEP 56320816, Petrolina, PE, Brasil

e-mail: alan_honorato18@hotmail.com

\section{FINANCIAL SUPPORT}

Conselho Nacional de Desenvolvimento Científico e Tecnológico (CNPq).

\section{REFERENCES}

Balota EL, Machineski O, Stenzel NMC. Resposta da acerola à inoculação de fungos micorrízicos arbusculares em solo com diferentes níveis de fósforo. Bragantia 2011; 70(1): 166-175. 10.1590/ S0006-87052011000100023
Carvalho F, Godoy EL, Lisboa FJ, Moreira FMS, Souza FA, Berbara RLL et al. Relationship between physical and chemical soil attributes and plant species diversity in tropical mountain ecosystems from Brazil. Journal of Mountain Science 2014; 11(4): 875-883. 10.1007/ s11629-013-2792-4

Couto JMF, Otoni WC, Pinheiro AL, Fonseca EP. Desinfestação e germinação in vitro de sementes de mogno (Swietenia macrophylla King). Revista Árvore 2004; 28(5): 633-642. 10.1590/S010067622004000500002

Drummond JA, Franco JLDA, Oliveira DD. Uma análise sobre a história e a situação das unidades de conservação no Brasil. In: Ganem RS, editor. Conservação da biodiversidade: legislação e políticas públicas. Brasília, DF: Câmara; 2011. p. 341-385.

Engelmoer DJP, Behm JE, Kiers ET. Intense competition between arbuscular mycorrhizal mutualists in an in vitro root microbiome negatively affects total fungal abundance. Molecular Ecology 2014; 23(6): 1584-1593. 10.1111/mec.12451

Folli-Pereira MS, Meira-Haddad LS, Bazzolli DMS, Kasuya MCM. Micorriza arbuscular e a tolerância das plantas ao estresse. Revista Brasileira de Ciência do Solo 2012: 36(6): 1663-1679. 10.1590/ S0100-06832012000600001

França AC, Carvalho FP, Franco MH, Avelar M, Souza BP, Stürmer SL. Crescimento de mudas de cafeeiro inoculadas com fungos micorrízicos arbusculares. Revista Brasileira de Ciências Agrárias 2014; 9(4): 506-511. 10.5039/agraria.v9i4a3938

Gerdeman JW, Nicolson TH. Spores of mycorrhizal Endogene species extracted from soil by wet sieving and decanting. Transactions of the British Mycological Society 1963; 46(2): 235- 244.

Giovanetti M, Mosse B. An evaluation of techniques for measuring vesicular-arbuscular mycorrhizal infection in roots. New Phytologist 1980; 84(3): 489-500. 10.1111/j.1469-8137.1980.tb04556.x

Gosling P, Mead A, Proctor M, Hammond JP, Bending GD. Contrasting arbuscular mycorrhizal communities colonizing different host plants show a similar response to a soil phosphorus concentration gradient. New Phytologist 2013; 198(2): 546-556. 10.1111/nph.12169

Jansa J, Smith FA, Smith SE. Are there benefits of simultaneous root colonization by different arbuscular mycorrhizal fungi? New Phytologist 2008; 177(3): 779-789.

Jenkins WR. A rapid centrifugal-flotation technique for separating nematodes from soil. Plant Disease Reporter 1964; 48(9): 692.

Knegt B, Jansa J, Franken O, Engelmoer DJP, Werner GDA, Bücking $\mathrm{H}$, Kiers ET. Host plant quality mediates competition between arbuscular mycorrhizal fungi. Fungal Ecology 2016; 20: 233-240. 10.1016/j.funeco.2014.09.011

Lins CEL, Maia LC, Cavalcante UMT, Sampaio EVSB. Efeito de fungos micorrízicos arbusculares no crescimento de mudas de Leucaena leucocephala (lam.) de wit. em solos de Caatinga sob impacto de mineração de cobre. Revista Árvore 2007; 31(2): 355363. $10.1590 /$ S0100-67622007000200019

Maia LC, Silva GA, Yano-Melo AM, Goto BT. Fungos micorrízicos arbusculares no bioma Caatinga. In: Siqueira JO, Souza FA, Cardoso EJBN, Tsai SM, editores. Micorrizas: 30 anos de pesquisas no Brasil. Lavras: Editora UFLA; 2010. p. 311-339. 
Mendes MMC, Chaves LFC, Pontes Neto TP, Silva JAA, Figueiredo MVB. Crescimento e sobrevivência de mudas de sabiá (Mimosa caesalpiniaefolia Benth.) inoculadas com micro-organismos simbiontes em condições de campo. Ciência Florestal 2013; 23(2): 309-320. 10.5902/198050989277

Nascimento JML, Moraes TAL, Silva EM, Melo NF, Yano-Melo AM. Crescimento de plantas de Bauhinia cheilanta micorrizadas em dois tipos de solo do bioma Caatinga. Revista Brasileira de Ciências Agrárias 2014; 9(4): 570-576. 10.5039/agraria.v9i4a4560

Novais RF, Smyth TJ, Nunes FV. Fósforo. In: Novais RF, Alvarez VVH, Barros NF, Fontes RLF, Cantarutti RB, Neves JCL, editores. Fertilidade do solo. Viçosa: Sociedade Brasileira de Ciência do Solo; 2007. p. 471-537.

Nunes JLS, Souza PVDD, Marodin GAB, Fachinello JC. Desenvolvimento de plântulas de pessegueiro 'Okinawa' inoculadas com micorrizas arbusculares isoladas de pomares de pessegueiros e de vinhedos. Revista Brasileira de Fruticultura 2013; 35(3): 845-852. 10.1590/S0100-29452013000300022

Oliveira JJF, Sousa RF, Carneiro RFV, Fonseca JM. Crescimento inicial de plantas de leucena frente à inoculação micorrízica e adubação orgânica. Revista Brasileira de Agroecologia 2013; 8(3): 212-220.

Oliveira JRG, Resende GM, Melo NF, Yano-Melo AM. Symbiotic compatibility between arbuscular mycorrhizal fungi (autoctone or exotic) and three native species of the Caatinga in different phosphorus levels. Acta Scientiarum, Biological Sciences 2017; 39(1): 50-69. 10.4025/actascibiolsci.v39i1.33486

Oliveira JRG, Teixeira-Rios T, Melo NFD, Yano-Melo AM. Response of an endangered tree species from Caatinga to mycorrhization and phosphorus fertilization. Acta Botanica Brasílica 2015; 29(1): 94-102. 10.1590/0102-33062014abb3420

Oliveira MS, Campos MA, Silva FS. Arbuscular mycorrhizal fungi and vermicompost to maximize the production of foliar biomolecules in Passiflora alata Curtis seedlings. Journal of the Science of Food and Agriculture 2015; 95(3): 522-528. 10.1002/jsfa.6767

Pedone-Bonfim MVL, Lins MA, Coelho IR, Santana AS, Silva FS, Maia LC. Mycorrhizal technology and phosphorus in the production of primary and secondary metabolites in cebil (Anadenanthera colubrina (Vell.) Brenan) seedlings. Journal of the Science of Food and Agriculture 2013; 93(6): 1479-1484. 10.1002/jsfa.5919

Pedone-Bonfim MVL, Silva DKA, Maia LC, Yano-Melo AM. Mycorrhizal benefits on native plants of the Caatinga, a Brazilian dry tropical forest. Symbiosis 2017; 74(3): 1-10. 10.1007/s13199-017-0510-7

Phillips JM, Hayman DS. Improved procedures for clearing roots and staining parasitic and vesicular-arbuscular mycorrhizal fungi for rapid assessment of infection. Transactions of the British Mycological Society 1970; 55(1): 158-161. 10.1016/S0007-1536(70)80110-3

Pouyu-Rojas E, Siqueira JO, Santos JGD. Compatibilidade simbiótica de fungos micorrízicos arbusculares com espécies arbóreas tropicais.
Revista Brasileira Ciência do Solo 2006; 30(3): 413-424. 10.1590/ S0100-06832006000300003

R Core Team. R: A language and environment for statistical computing. Vienna: R Foundation for Statistical Computing; 2016.

Saboya RCC, Chagas AF Jr, Monteiro FPR, Santos GR, Erasmo EAL, Chagas LFB. Fungos micorrízicos arbusculares afetando a produção de mudas de pinhão manso na região sul do estado de Tocantins, Brasil. Revista Ceres 2012; 59(1): 142-146. 10.1590/ S0034-737X2012000100020

Scremin-Dias E, Kalife C, Menegucci ZRH, Souza PRD. Produção de mudas de espécies florestais nativas: manual. Campo Grande: Editora UFMS; 2006.

Silva APM, Marques HR, Santos TVMN, Teixeira AMC, Luciano MSF, Sambuichi RHR. Diagnóstico da produção de mudas florestais nativas no Brasil. Brasília, DF: Ipea; 2015.

Siqueira Filho JA. Flora das Caatingas do Rio São Francisco: história natural e conservação. Rio de Janeiro: Andrea Jakobsson Estúdio; 2012.

Smith SE, Read DJ. Mycorrhizal symbiosis. 3rd ed. London: Academic Press; 2008.

Smith SE, Smith FA. Fresh perspectives on the roles of arbuscular mycorrhizal fungi in plant nutrition and growth. Mycologia 2012; 104(1): 1-13. 10.3852/11-229

Sugai MAA, Collier LS, Saggin-Júnior OJ. Inoculação micorrízica no crescimento de mudas de angico em solo de cerrado. Bragantia 2011; 70(2): 416-423. 10.1590/S0006-87052011000200024

Tavares RC, Mendes Filho PF, Lacerda CF, Silva J. Colonização micorrízica e nodulação radicular em mudas de sabiá (Mimosa caesalpiniaefolia Benth.) sob diferentes níveis de salinidade. Revista Ciência Agronômica 2012; 43(3): 409-416. 10.1590/S180666902012000300001

Teixeira-Rios T, Oliveira JRG, Yano-Melo AM. Arbuscular mycorrhizal fungi and phosphorus in the initial development of Mimosa tenuiflora (Willd.) Poir. Brazilian Journal of Botany 2016; 39(4): 997-1004. 10.1007/s40415-016-0297-4

Vale FXR, Fernandes Filho EI, Liberato JR. Quant, versão 1.0.1. Viçosa: Universidade Federal de Viçosa; 2003.

Violi HA, Treseder KK, Menge JA, Wright SF, Lovatt CJ. Density, dependence and interspecific interactions between arbuscular mycorrhizal fungi mediated plant growth, glomalin production, and sporulation. Canadian Journal of Botany 2007; 85(1): 63-75. $10.1139 / \mathrm{b} 06-151$

Weber OB, Souza CCM, Gondin DMF, Oliveira FNS, Crisóstomo LA, Caproni AL, Saggin O Jr. Inoculação de fungos micorrízicos arbusculares e adubação fosfatada em mudas de cajueiro-anão-precoce. Pesquisa Agropecuária Brasileira 2004; 39(5): 477-483. 10.1590/S0100-204X2004000500010 